\title{
A REVIEW OF THE CLINICAL APPLICABILITY OF SPEECH-EVOKED AUDITORY BRAINSTEM RESPONSES
}

\author{
Milaine Dominici Sanfins, Maria Francisca Colella-Santos \\ Medical Sciences College, University of Campinas, Campinas, SP, Brazil
}

Corresponding author: Milaine Dominici Sanfins, Rua Visconde de Cachoeira, 33-apto 72, Vila Nova

Conceição, São Paulo-SP, 04512-030,Brazil, e-mail: msanfins@uol.com.br

\begin{abstract}
Through a systematic literature review, this paper evaluates the clinical applicability of speech-evoked auditory brainstem responses (ABRs). The survey was done on five databases, with the following key words: speech ABR; ABR-speech; speech auditory brainstem response; auditory evoked potential to speech; speech-evoked brainstem response; complex sounds; and CABR. The search generated a list of 1288 items published between 2005 and 2015. After applying pre-established criteria of inclusion and exclusion, 21 publications remained. The collected data show that: (i) research on speech ABR has been done on diverse age groups, although teenagers and adolescents have been less studied; (ii) the speech ABR procedure has been shown to be a reliable and effective tool in evaluating the coding of speech sounds in the brainstem, and can also be applied to young children; and (iii) speech ABR has been shown to be effective in the differential diagnosis of diseases with similar features and symptoms.
\end{abstract}

Key words: auditory brainstem response • speech • speech ABR • central auditory processing

\section{DESCRIPCIÓN CLÍNICA GENERAL DE LAS APLICACIONES AUDITIVAS DE LOS POTENCIALES DEL TRONCO CEREBRAL EVOCADO POR EL HABLA}

\begin{abstract}
Resumen
Este estudio evalúa la aplicación clínica de los potenciales auditivos del tronco cerebral evocados por el habla (ABRs) a través de una revisión sistemática de la literatura. La revisión se realizó en cinco bases de datos con palabras clave en inglés en diversas formas que indicaban los potenciales auditivos evocados por habla: speech ABR, ABR-speech, speech auditory brainstem response; auditory evoked potential to speech; speech-evoked brainstem response, así como sonidos complejos (complex sounds) y cABR. El buscador encontró una lista de 1288 artículos publicados entre 2005 y 2015. Después de aplicar criterios preestablecidos de inclusión y exclusión quedaron 21 artículos. Los datos recogidos muestran que (i) el estudio de potenciales auditivos evocados por el habla se realizan en diferentes grupos de edad de los pacientes, a pesar de que los adolescentes y los adultos se examinan menos, (ii) el estudio de potenciales auditivos evocados por el habla es una herramienta fiable y eficaz para evaluar la codificación de los sonidos del habla en el tronco del cerebro y se puede realizar en niños pequeños, (iii) el estudio de los potenciales auditivos evocados por el habla es una herramienta eficaz para el diagnóstico diferencial de enfermedades con características y síntomas similares.
\end{abstract}

Palabras clave: potenciales auditivo del tronco cerebral • el habla • potenciales auditivos evocados por el habla • procesamiento auditivo central

\section{ОБЗОР КЛИНИЧЕСКИХ ПРИМЕНЕНИЙ СЛУХОВЫХ СТВОЛОМОЗГОВЫХ ПОТЕНЦИАЛОВ, ВЫЗВАННЫХ РЕЧЬЮ}

\section{Изложение}

Настоящая работа оценивает клиническое применение слуховых стволомозговых потенциалов, вызванных речью (ABRs) путем систематического обзора литературы. Обзор был произведен в пяти базах данных с ключевыми словами на английском языке в разной форме, означающими слуховые потенциалы, вызванные речью: speесh ABR, ABR-speech, speech auditory brainstem response; auditory evoked potential to speech; speech-evoked brainstem response, а также сложные звуки (complex sounds) и сABR. Поисковая система нашла список 1288 пунктов, изданных между 2005 и 2015 годом. После применения зараннее установленных критериев отбора и исключения, остался 21 пункт. Собранные данные показывают, что (I) исследования слуховых потенциалов, вызванных речью, проводятся у пациентов разных возрастных групп, хотя люди юношеского возраста и взрослые обследованы реже, (II) исследование слуховых потенциалов, вызванных речью, является тщательным и эффективным 
инструментом для оценки кодирования речевых сигналов в стволе мозга, его можно проводить у маленьких детей, (III) исследование слуховых потенциалов, вызванных речью, является эффективным инструментом для дифференциальной диагностики заболеваний, имеющих подобные свойства и симптомы.

Ключевые слова: вызванные слуховые стволомозговые потенциалы • речь • слуховые потенциалы • вызванные речью • центральная слуховая переработка

\section{PRZEGLĄD KLINICZNYCH ZASTOSOWAŃ SŁUCHOWYCH POTENCJAŁÓW PNIA MÓZGU WYWOŁANYCH MOWĄ}

\section{Streszczenie}

Niniejsza praca ocenia kliniczne zastosowanie słuchowych potencjałów pnia mózgu wywołanych mową (ABRs) poprzez systematyczny przegląd literatury. Przegląd został wykonany na pięciu bazach danych ze słowami kluczowymi w języku angielskim w różnej formie oznaczającymi słuchowe potencjały wywołane mową: speech ABR, ABR-speech, speech auditory brainstem response; auditory evoked potential to speech; speech-evoked brainstem response, a także dźwięki złożone (complex sounds) i cABR. Wyszukiwarka znalazła listę 1288 pozycji opublikowanych pomiędzy 2005 i 2015 rokiem. Po zastosowaniu wcześniej ustalonych kryteriów włączania i wyłączania, pozostało 21 pozycji. Zebrane dane pokazują, że (i) badania słuchowych potencjałów wywołanych mową są przeprowadzane na różnych grupach wiekowych pacjentów, choć nastolatkowie i osoby dorosłe są badanie rzadziej, (ii) badanie słuchowych potencjałów wywołanych mową jest rzetelnym i efektywnym narzędziem do oceny kodowania dźwięków mowy w pniu mózgu i może być wykonywane u małych dzieci, (iii) badanie słuchowych potencjałów wywołanych mową jest efektywnym narzędziem do diagnostyki różnicowej chorób o podobnych cechach i objawach.

Słowa kluczowe: słuchowe potencjały wywołane pnia mózgu • mowa • słuchowe potencjały wywołane mową • ośrodkowe przetwarzanie słuchowe

\section{Background}

The auditory brainstem response (ABR) provides diagnostic information about the pathway from the auditory periphery to the brainstem, and is routinely used in the clinic to assess hearing function. Traditionally, ABR responses are evoked by transient non-verbal stimuli. ABR is used to assess the integrity of auditory pathways, enabling basic neural abnormalities to be identified and helping to evaluate patients who failed to provide reliable answers in behavioral audiological evaluations [1]. Recent technological developments [2] have proposed a new ABR stimulus paradigm consisting of verbal stimuli. Such a stimulus modality can help in understanding how a speech stimulus is processed in the brainstem.

Speech is characterized by three main components: pitch, formants, and timing of acoustic landmarks. Any difficulty in processing these aspects will lead to difficulties in processing auditory information and the perception of speech sounds, both of which can be used to diagnose oral or written language disorders [3]. The brainstem plays an essential role in the mechanism of speech perception, as in reading or the acquisition of phonological information [4-6].

Speech-evoked ABRs (speech ABRs) have been carried out using different verbal stimuli. The best-known is elicited by the synthesized syllable /da/, provided by a computer. The creator of this stimulus is Dr Nina Kraus of Northwestern University. The stimulus consists of the consonant /d/ (the transient portion or onset) and the short vowel /a/ (the sustained portion or frequency following response). The ABR elicited by this stimulus is a complex wave consisting of seven peaks: V, A, C, D, E, F, and O. The only wave with a positive peak is the complex wave $\mathrm{V}$. The $\mathrm{V}$ and $\mathrm{A}$ waves reflect highly synchronized neural responses to the onset of the stimulus. The $\mathrm{C}$ wave represents the transition between consonant and vowel, whereas the $\mathrm{O}$ wave represents the end of the vowel [7-9]. A typical speech ABR response is depicted in Figure 1.

Recent research has highlighted the role and clinical applicability of speech ABR. The results have shown that it is an objective, fast, and effective procedure. It does not require the patient's conscious participation and provides data on neural maturation and the central auditory neural system (CANS). Therefore, speech ABR can function as a biomarker for numerous conditions including scholastic difficulties [9], psychosis [10], learning disabilities [11], and auditory processing [8].

The aim of this paper is to present an update on the clinical availability of speech ABR protocols through a systematic review of the literature over the last 10 years.

\section{Materials and methods}

The selected articles for this review were published in journals indexed in the following databases: (i) US National Library of Medicine and National Institute of Health (PubMed); (ii) Scientific Electronic Library Online (Scielo); (iii) Latin American and Caribbean Health Sciences (Lilacs); (iv) Scopus; and (v) ISI Web of Science. The descriptors were restricted to the English language, according to the Medical Subject Headlings (MeSH). The following terms were searched: speech ABR, ABR-speech, speech auditory brainstem response, auditory evoked potential to speech, speech-evoked brainstem response, complex sounds, and cABR. 


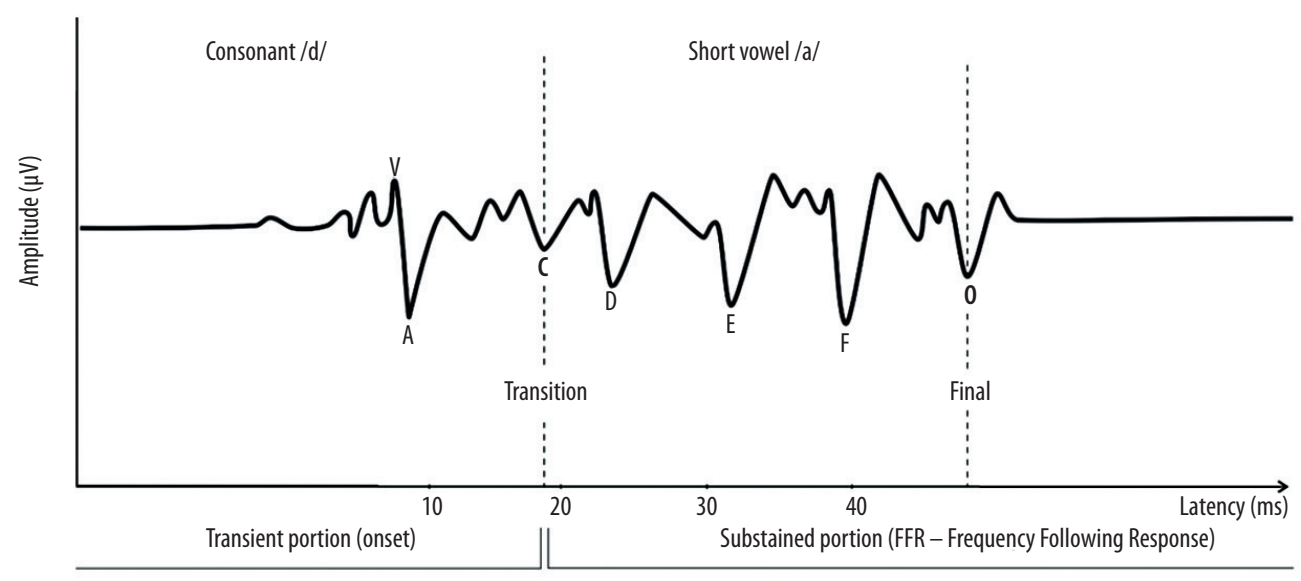

Figure 1. Typical speech ABR response, showing electrophysiological response to synthesized syllable /da/. From a personal file of the investigator using an assessment performed with BioMARK software [7]

The review was conducted by the two authors independently and disagreements were resolved through discussion. For selection of the papers the following inclusion criteria were used: (i) articles published in the last 10 years (2005-15); (ii) original articles only. The exclusion criteria consisted of: (i) animal experiments; (ii) case studies; (iii) literature reviews; (iv) articles not in English.

The information gathered from papers passing the inclusion criteria consisted of the following data: (i) objectives of the studies; (ii) characterization of the sample (i.e. number of subjects, age, gender, and native language); (iii) disorders studied; (iv) preliminary and final evaluations; and (v) final conclusions and future suggestions.

\section{Results}

The initial search resulted in a pool of 1288 papers related to speech ABR. Papers were excluded from the pool for the following reasons: duplicate/similar studies from the same research groups ( $n=887)$; (b) experimental animal studies; unpublished articles in English; case studies; literature reviews $(n=377)$; and (c) after an evaluation of the paper by the two reviewers $(n=3)$. A total number of 21 articles were used for this review.

The flowchart of the article selection process is shown in Figure 2. Table 1 shows in schematical form the data collected from the included papers.

\section{Discussion}

The sampled subjects included children, adolescents, young adults, and older adults for a total of 1238 subjects, with an age span of 5-80 years. The number of individuals included in each study ranged from 4 to 235 . As a relatively new diagnostic tool, it was possible to identify that young adults and/or adults were the most studied $(66.6 \%$ of articles). The main reason for this age-selection was probably the better consistency of the speech-ABR response in adults due to maturation. Data collection is also easier in these cases, since adults better understand the necessary clinical requirements. In contrast, publications with data

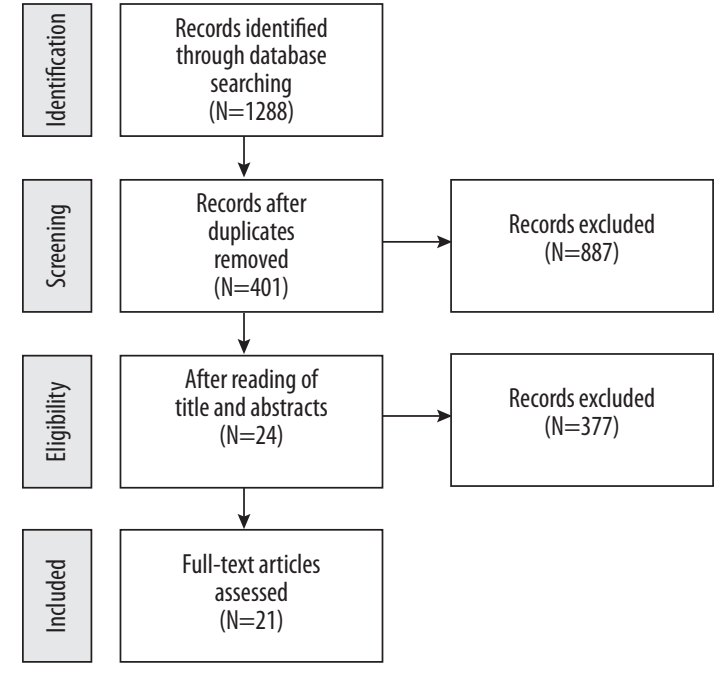

Figure 2. Flowchart of the article selection process used here

from children and teenagers are more scarce (14.3\% of publications). More normative studies are needed in children and adolescents in order to establish a normal reference range so that more accurate diagnosis and monitoring of auditory rehabilitation can be done.

In 14 articles (66.6\%), only healthy individuals with normal development were evaluated. In 7 articles (33.3\%), subjects with various disorders were studied and compared with normal subjects via Control-CG waves. The studied disorders included: auditory processing disorder and specific language impairment [14,15]; learning disabilities; dyslexia; epilepsy; persistent developmental stuttering, and hearing loss [12,13,16-18]. In addition, other aspects of a subject's clinical history were assessed. In the study of Hornichel et al. [19], a comparative analysis was carried out on groups of children whose parents had a proven history of reading problems. The data showed that speech ABR can predict the risk of these children having reading difficulties. 
Table 1. Summary of articles on speech ABR

\begin{tabular}{|c|c|c|c|c|c|c|c|}
\hline Article & No. & Sample & $\begin{array}{l}\text { Age range } \\
(\text { mean } \pm s d)\end{array}$ & $\begin{array}{c}\text { Native } \\
\text { language }\end{array}$ & $\begin{array}{l}\text { Preliminary } \\
\text { evaluation }\end{array}$ & $\begin{array}{c}\text { Comple- } \\
\text { mentary } \\
\text { evaluation }\end{array}$ & Conclusions \\
\hline $\begin{array}{l}\text { Bellier } \\
\text { et al., } \\
2015\end{array}$ & 1 & $\begin{array}{l}\text { SG: } 4 \text { healthy individuals } \\
\text { (3 female) }\end{array}$ & $\underline{\mathrm{SG}}: 22-25 \mathrm{yr}$ & French & PTA & - & $\begin{array}{l}\text { The results open new } \\
\text { perspectives for improving } \\
\text { the adaptation of hearing } \\
\text { aids using the extensive } \\
\text { information provided by this } \\
\text { electrophysiological marker }\end{array}$ \\
\hline
\end{tabular}

\begin{tabular}{|c|c|c|c|c|c|c|c|}
\hline $\begin{array}{l}\text { Fujihira } \\
\text { et al., } \\
2015\end{array}$ & 2 & $\begin{array}{l}\text { SG: } 30 \text { healthy female } \\
\text { individuals }\end{array}$ & $\begin{array}{l}\frac{S G}{(66.9 \pm 3.4)} 61-73 y r \\
(66.9\end{array}$ & Japanese & PTA & WIP test & $\begin{array}{l}\text { The speech intelligibility } \\
\text { in reverberation in elderly } \\
\text { listeners is related to its ability } \\
\text { to encode the temporal aspects } \\
\text { of speech }\end{array}$ \\
\hline
\end{tabular}

\begin{tabular}{|c|c|c|c|c|c|c|c|}
\hline $\begin{array}{l}\text { Mamo } \\
\text { et al., } \\
2015\end{array}$ & 3 & $\begin{array}{l}\text { SG 1: } 22 \text { healthy young } \\
\text { adults (17 female) } \\
\text { SG 2: } 22 \text { healthy older } \\
\text { adults (15 female) }\end{array}$ & 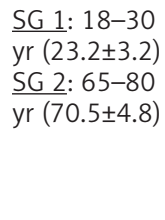 & English & PTA & - & $\begin{array}{l}\text { The elderly have reduced } \\
\text { neural synchrony for encoding } \\
\text { periodic signals, the complex } \\
\text { of the brainstem. The reduced } \\
\text { sync can be modeled by } \\
\text { simulating jitter by interrupting } \\
\text { the stimulus waveform }\end{array}$ \\
\hline
\end{tabular}

\begin{tabular}{|c|c|c|c|c|c|c|c|}
\hline $\begin{array}{l}\text { Ahadi } \\
\text { et al., } \\
2014\end{array}$ & 4 & $\begin{array}{l}\text { SG: } 48 \text { healthy young } \\
\text { individuals ( } 25 \text { female) }\end{array}$ & $\frac{S G}{(22.77 \pm 2.05)}$ & Persian & $\begin{array}{l}\text { PTA and } \\
\text { immittance }\end{array}$ & - & $\begin{array}{l}\text { The evoked potentials of } \\
\text { the response time are not } \\
\text { related to the stimulus } \\
\text { presentation mode. Binaural } \\
\text { stimulation produces more } \\
\text { robust responses. The } \\
\text { lateral asymmetry in the } \\
\text { representation of speech } \\
\text { elements is not significant in } \\
\text { the brainstem }\end{array}$ \\
\hline
\end{tabular}

\begin{tabular}{|c|c|c|c|c|c|c|c|}
\hline $\begin{array}{l}\text { Elkabariti } \\
\text { et al., } \\
2014\end{array}$ & 5 & 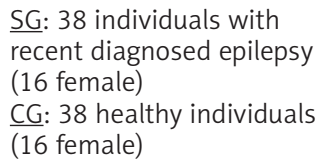 & $\begin{array}{l}\frac{S G}{(9.1 \pm 3} 5-15 \mathrm{yr} \\
\frac{\mathrm{CG}: 5-15 \mathrm{yr}}{(9.2 \pm 3)}\end{array}$ & - & $\begin{array}{l}\text { PTA, SA, } \\
\text { immittance, } \\
\text { and } \\
\text { questionnaire }\end{array}$ & ABR (click) & $\begin{array}{l}\text { The abnormal response can be } \\
\text { detected only with the speech } \\
\text { stimulus and not the click } \\
\text { stimulus from the epileptic } \\
\text { group }\end{array}$ \\
\hline
\end{tabular}

\begin{tabular}{|c|c|c|c|c|c|c|c|}
\hline $\begin{array}{l}\text { Rocha- } \\
\text { Muniz } \\
\text { et al., } \\
2014\end{array}$ & 6 & $\begin{array}{l}\text { SG 1: } 25 \text { individuals with } \\
\text { APD (7 female) } \\
\text { SG 2: } 25 \text { individuals with } \\
\text { SLI (7 female) } \\
\text { CG: } 25 \text { individuals with TD } \\
\text { (13 female) }\end{array}$ & $\begin{array}{l}\frac{\text { SG 1: }}{(8.72)} 6-12 \mathrm{yr} \\
\frac{\text { SG 2: 6-12 yr }}{(7.84)} \\
\frac{\text { CG: 6-12 yr }}{(8 .)}\end{array}$ & $\begin{array}{l}\text { Brazilian } \\
\text { Portu- } \\
\text { guese }\end{array}$ & $\begin{array}{l}\text { PTA, SA, and } \\
\text { tympanometry. } \\
\text { SG 1: parents } \\
\text { and classroom } \\
\text { teacher } \\
\text { reports, AP test } \\
\text { SG 2: Leonard's } \\
\text { diagnosis, } \\
\text { ABFW Child } \\
\text { Language Test, } \\
\text { MLU, TELD-3, } \\
\text { and RAVEN } \\
\text { test } \\
\text { CG: AP test }\end{array}$ & - & $\begin{array}{l}\text { The values obtained were } \\
\text { similar to English speakers. The } \\
\text { speech ABR is useful to identify } \\
\text { auditory processing disorders } \\
\text { and language deficits. ABR } \\
\text { suggests that the speech } \\
\text { can be used clinically for the } \\
\text { assessment of central auditory } \\
\text { function and provide additional } \\
\text { information in language } \\
\text { disorders and diagnosis of } \\
\text { hearing processing deficits }\end{array}$ \\
\hline $\begin{array}{l}\text { Tahaei } \\
\text { et al., } \\
2014\end{array}$ & 7 & $\begin{array}{l}\text { SG: } 25 \text { individuals with } \\
\text { PDS (4 female) } \\
\text { CG: } 25 \text { healthy } \\
\text { individuals ( } 4 \text { female) }\end{array}$ & $\begin{array}{l}\text { SG: } 16-35 \mathrm{yr} \\
(24.48 \pm 3.99) \\
\frac{\mathrm{CG}: 16-35 \mathrm{yr}}{(22.44 \pm 2.32)}\end{array}$ & Persian & $\begin{array}{l}\text { ABR (click), } \\
\text { PTA, SSI-3, } \\
\text { and Edinburgh } \\
\text { handedness } \\
\text { questionnaire }\end{array}$ & - & $\begin{array}{l}\text { The SG shows a poor neural } \\
\text { synchronization in the early } \\
\text { stages of the auditory pathway } \\
\text { with temporal processing } \\
\text { deficits. This difficulty can } \\
\text { be the basis of a presented } \\
\text { disfluency. }\end{array}$ \\
\hline $\begin{array}{l}\text { Anderson } \\
\text { et al., } \\
2013\end{array}$ & 8 & $\begin{array}{l}\text { SG: } 111 \text { individuals } \\
\text { (64 female) with hearing } \\
\text { levels ranging from } \\
\text { normal hearing to } \\
\text { moderate hearing loss }\end{array}$ & $\frac{\mathrm{SG}:}{(61.1)}$ & English & $\begin{array}{l}\text { PTA, ABR } \\
\text { (click), IQ } \\
\text { scores from } \\
\text { WASI, and } \\
\text { MoCA }\end{array}$ & $\begin{array}{l}\text { SSQ hearing } \\
\text { performance } \\
\text { and QuickSIN }\end{array}$ & $\begin{array}{l}\text { The results demonstrate a } \\
\text { possible link between the } \\
\text { offset of the delay, reduced } \\
\text { morphology, and speech } \\
\text { perception in noise }\end{array}$ \\
\hline
\end{tabular}




\begin{tabular}{|c|c|c|c|c|c|c|c|}
\hline Article & No. & Sample & $\begin{array}{c}\text { Age range } \\
\text { (mean } \pm \mathrm{sd})\end{array}$ & $\begin{array}{l}\text { Native } \\
\text { language }\end{array}$ & $\begin{array}{l}\text { Preliminary } \\
\text { evaluation }\end{array}$ & $\begin{array}{l}\text { Comple- } \\
\text { mentary } \\
\text { evaluation }\end{array}$ & Conclusions \\
\hline $\begin{array}{l}\text { Clinard } \\
\text { et al., } \\
2013\end{array}$ & 9 & $\begin{array}{l}\text { SG: } 34 \text { individuals } \\
\text { (30 female), right-handed, } \\
\mathrm{NH}, \text { no otological or } \\
\text { neurological disorders }\end{array}$ & $\underline{\text { SG: }} 22-77 \mathrm{yr}$ & English & $\begin{array}{l}\text { PTA and } \\
\text { immittance }\end{array}$ & - & $\begin{array}{l}\text { Biological aging affects the } \\
\text { decoding of simple and } \\
\text { complex sounds; neural timing } \\
\text { decreases with advancing } \\
\text { age and can be seen during } \\
\text { adulthood, and then in middle } \\
\text { age, even in normal listening } \\
\text { conditions. The speech ABR } \\
\text { can be used in audiological } \\
\text { monitoring }\end{array}$ \\
\hline
\end{tabular}

\begin{tabular}{|c|c|c|c|c|c|c|}
\hline $\begin{array}{l}\text { Hornickel } 10 \\
\text { et al., } \\
2012\end{array}$ & $\begin{array}{l}\text { SG session year } 1: \\
26 \text { individuals with TD } \\
(12 \text { female) } \\
\frac{\text { SG session year } 2:}{25 \text { individuals with TD }} \\
\text { (12 female) }\end{array}$ & $\begin{array}{l}\frac{\text { SG 1 : }}{(10.5)} 8-13 \mathrm{yr} \\
\frac{\text { SG 2: }}{(10.5)}\end{array}$ & English & $\begin{array}{l}\text { PTA, IQ scores } \\
\text { from WASI, } \\
\text { ABR (click), and } \\
\text { TOWRE }\end{array}$ & - & $\begin{array}{l}\text { The speech ABR is replicable } \\
\text { and consistent over a year of } \\
\text { growth in children with typical } \\
\text { development. The speech } \\
\text { ABR may contribute to the } \\
\text { clinical evaluation of auditory } \\
\text { processing in children of school } \\
\text { age }\end{array}$ \\
\hline
\end{tabular}

\begin{tabular}{|c|c|c|c|c|c|c|c|}
\hline $\begin{array}{l}\text { Kouni } \\
\text { et al., } \\
2013\end{array}$ & 11 & $\begin{array}{l}\text { SG 1: } 10 \text { individuals with } \\
\text { dyslexia } \\
\text { SG 2: } 10 \text { individuals with } \\
\text { OLD } \\
\text { CG: } 20 \text { healthy individuals } \\
\text { SG1 + SG2: } 12 \text { female }\end{array}$ & $\begin{array}{l}\text { SG } 1+2: \\
18-23 \text { yr }(20) \\
\text { CG: } \\
19-22 \mathrm{yr} \\
(20.5)\end{array}$ & Greek & $\begin{array}{l}\text { PTA, IQ scores } \\
\text { from WAIS-IV, } \\
\text { SDT, and } \\
\text { tympanometry }\end{array}$ & ABR (click) & $\begin{array}{l}\text { The start of neural synchrony } \\
\text { differs between normal } \\
\text { subjects and some young } \\
\text { adults with dyslexia. Speech } \\
\text { ABR can be used to identify } \\
\text { children at risk for learning } \\
\text { problems and dyslexia before } \\
\text { school age }\end{array}$ \\
\hline
\end{tabular}

\begin{tabular}{|c|c|c|c|c|c|c|c|}
\hline $\begin{array}{l}\text { Hornickel } \\
\text { et al., } \\
2013\end{array}$ & 12 & $\begin{array}{l}\text { SG: } 113 \text { individuals ( } 30 \\
\text { female), NH. Divided into } \\
\text { four groups based on } \\
\text { their siblingship, reading } \\
\text { abilities, age and sex }\end{array}$ & $\begin{array}{l}6.5-14.10 \mathrm{yr} \\
(11.3)\end{array}$ & English & $\begin{array}{l}\text { PTA, PEATE } \\
\text { (click), IQ score } \\
\text { from WAIS, } \\
\text { TOWRE, and } \\
\text { TOSWRF }\end{array}$ & - & $\begin{array}{l}\text { Speech } A B R \text { is a measure } \\
\text { that can be used to evaluate } \\
\text { reading problems in children }\end{array}$ \\
\hline $\begin{array}{l}\text { Rocha- } \\
\text { Muniz } \\
\text { et al., } \\
2012\end{array}$ & 13 & $\begin{array}{l}\text { SG 1: } 18 \text { individuals with } \\
\text { APD (4 female) } \\
\text { SG 2: } 21 \text { individuals with } \\
\text { LI (5 female) } \\
\text { (8 female) }\end{array}$ & $\begin{array}{l}\text { SG 1: 6-12 } \\
\mathrm{yr}(110.00 \\
\pm 22.34 \\
\text { months) } \\
\text { SG 2: 6-12 yr } \\
\text { (96.00 } \pm 19.36 \\
\text { months) } \\
\text { CG: 6-12 } \\
\mathrm{yr}(109.83 \\
\pm 24.17 \\
\text { months) }\end{array}$ & $\begin{array}{l}\text { Brazilian } \\
\text { Portu- } \\
\text { guese }\end{array}$ & $\begin{array}{l}\text { PTA, SA, and } \\
\text { tympanometry. } \\
\text { SG 1: parents } \\
\text { and classroom } \\
\text { teacher } \\
\text { reports, AP test } \\
\text { SG 2: Leonard's } \\
\text { diagnosis, } \\
\text { ABFW, MLU, } \\
\text { TELD-3, and } \\
\text { RAVEN test } \\
\text { CG: AP test }\end{array}$ & 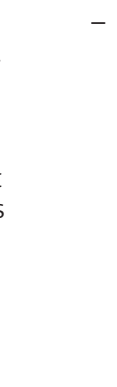 & $\begin{array}{l}\text { The Brazilian procedure can } \\
\text { be used to supplement the } \\
\text { diagnosis of speakers of } \\
\text { English, given that the values } \\
\text { found are similar. The results } \\
\text { also showed that it can be } \\
\text { used to identify auditory } \\
\text { processing disorder and loss } \\
\text { of language and additional } \\
\text { information in such cases }\end{array}$ \\
\hline $\begin{array}{l}\text { Rana } \\
\text { et al., } \\
2011\end{array}$ & 14 & $\begin{array}{l}\text { SG: } 35 \text { healthy } \\
\text { individuals } \\
\text { No CG }\end{array}$ & $\underline{\mathrm{SG}}: 18-23 \mathrm{yr}$ & Indian & $\begin{array}{l}\text { PTA, } \\
\text { immittance, } \\
\text { and normal } \\
\text { auditory } \\
\text { processing } \\
\text { (speech in } \\
\text { noise test) }\end{array}$ & TEOAE & $\begin{array}{l}\text { The combination of the EOAT } \\
\text { and speech ABR in battery } \\
\text { of tests can help identify the } \\
\text { location of different disorders }\end{array}$ \\
\hline $\begin{array}{l}\text { Song } \\
\text { et al., } \\
2011\end{array}$ & 15 & $\begin{array}{l}\text { GS 1: } 31 \text { individuals ( } 20 \\
\text { female) tested with the } \\
170 \text { ms /da/ in quiet and } \\
\text { background noise. Mean } \\
\text { time between Tests } 1 \text { and } \\
2 \text { was } 58( \pm 33) \text { days. } \\
\text { GS 2: } 45 \text { healthy } \\
\text { individuals ( } 29 \text { female) } \\
\text { tested with the } 40 \mathrm{~ms} \\
/ \text { da/. Mean time between } \\
\text { Tests } 1 \text { and } 2 \text { was } 41( \pm 34) \\
\text { days }\end{array}$ &  & English & $\begin{array}{l}\text { IQ score from } \\
\text { WAIS, TONI-3, } \\
\text { PTA, ABR (click) }\end{array}$ & - & $\begin{array}{l}\text { The speech ABR proves to } \\
\text { be useful in the evaluation } \\
\text { of adults and young people } \\
\text { in consistency in coding a } \\
\text { complex sound at the pre- } \\
\text { conscious level }\end{array}$ \\
\hline
\end{tabular}




\begin{tabular}{|c|c|c|c|c|c|c|c|}
\hline Article & No. & Sample & $\begin{array}{c}\text { Age range } \\
\text { (mean } \pm s d)\end{array}$ & $\begin{array}{c}\text { Native } \\
\text { language }\end{array}$ & $\begin{array}{l}\text { Preliminary } \\
\text { evaluation }\end{array}$ & $\begin{array}{l}\text { Comple- } \\
\text { mentary } \\
\text { evaluation }\end{array}$ & Conclusions \\
\hline $\begin{array}{l}\text { Karawani } \\
\text { et al., } \\
2010\end{array}$ & 16 & $\begin{array}{l}\text { SG 1: } 20 \text { healthy } \\
\text { individuals Arabic } \\
\text { speakers } \\
\text { SG 2: } 14 \text { healthy } \\
\text { individuals Hebrew } \\
\text { speakers }\end{array}$ & $\begin{array}{l}\frac{\text { SG1 and SG2: }}{18-28 \mathrm{yr}} \\
(23.5 \pm 1.67)\end{array}$ & $\begin{array}{l}\text { Hebrew } \\
\text { and } \\
\text { Arabic }\end{array}$ & $\begin{array}{l}\text { PTA, } \\
\text { information } \\
\text { concerning } \\
\text { language } \\
\text { background } \\
\text { and musical } \\
\text { experience }\end{array}$ & ABR (click) & $\begin{array}{l}\text { ABR speech is similar in } \\
\text { speakers of Hebrew, Arabic, } \\
\text { and English (normative data). It } \\
\text { suggests that the basis of the } \\
\text { US procedure can be used for } \\
\text { non-English speakers }\end{array}$ \\
\hline $\begin{array}{l}\text { Rocha } \\
\text { et al., } \\
2010\end{array}$ & 17 & $\begin{array}{l}\text { SG: } 50 \text { healthy } \\
\text { individuals } \\
\text { ( } 28 \text { female) }\end{array}$ & $\frac{\text { SG: } 19-32 \mathrm{yr}}{(23.56 \pm 3.13)}$ & $\begin{array}{l}\text { Brazilian } \\
\text { Portu- } \\
\text { guese }\end{array}$ & $\begin{array}{l}\text { PTA, SA, } \\
\text { tympanometry, } \\
\text { and AP test }\end{array}$ & ABR (click) & $\begin{array}{l}\text { Potentially this is a new tool } \\
\text { for the codification of sound } \\
\text { in brainstem regions with } \\
\text { independent quantifiable } \\
\text { measures of attention of the } \\
\text { subject }\end{array}$ \\
\hline $\begin{array}{l}\text { Sinha } \\
\text { et al., } \\
2010\end{array}$ & 18 & $\begin{array}{l}\text { SG: } 30 \text { healthy } \\
\text { individuals }\end{array}$ & $\underline{\mathrm{SG}}: 18-25 \mathrm{yr}$ & Indian & $\begin{array}{l}\text { PTA, SA, and } \\
\text { immittance }\end{array}$ & - & $\begin{array}{l}\text { Most applications can be in } \\
\text { diagnosis and categorization } \\
\text { of children with learning } \\
\text { disabilities. In other different } \\
\text { subgroups, the effect of age } \\
\text { on hearing can also be applied } \\
\text { to monitoring users of hearing } \\
\text { aids and cochlear implants }\end{array}$ \\
\hline $\begin{array}{l}\text { Akhoun } \\
\text { et al., } \\
2008 \text { a } \\
\text { (clinical) }\end{array}$ & 19 & $\begin{array}{l}\text { SG: } 23 \text { healthy } \\
\text { individuals }\end{array}$ & $\frac{\text { SG: }}{(24)} 19-48 \mathrm{yr}$ & French & - & - & $\begin{array}{l}\text { There was a close relationship } \\
\text { between the FFR and the } \\
\text { envelope of the vowel, whereas } \\
\text { the consonant had more effect } \\
\text { on the response onset }\end{array}$ \\
\hline $\begin{array}{l}\text { Akhoun } \\
\text { et al., } \\
2008 \mathrm{~b} \\
\text { (journal) }\end{array}$ & 20 & $\begin{array}{l}\text { SG: } 6 \text { unilateral impaired } \\
\text { individuals } \\
\text { CG: } 6 \text { normal hearing } \\
\text { individuals ( } 3 \text { female) }\end{array}$ & $\begin{array}{l}\text { SG: } 27-63 \mathrm{yr} \\
(51 \pm 12) \\
\frac{\mathrm{CG}: 19-27 \mathrm{yr}}{(21 \pm 5.0)}\end{array}$ & French & PTA & - & $\begin{array}{l}\text { In conditions free of artifacts it } \\
\text { was observed that the speech } \\
\text { ABR has neurophysiological } \\
\text { origin, as opposed to } \\
\text { artifactual origin. } \\
\text { (i) Insensitivity of speech ABR } \\
\text { polarity to the stimulus, (ii) } \\
\text { lag and low-pass filtering of } \\
\text { speech ABR, (iii) no speech } \\
\text { ABR in non-functional auditory } \\
\text { pathways }\end{array}$ \\
\hline $\begin{array}{l}\text { Song } \\
\text { et al., } \\
2006\end{array}$ & 21 & $\begin{array}{l}\text { SG: } 119 \text { individuals } \\
\text { with LP } \\
\text { CG: } 115 \text { individuals } \\
\text { with NL }\end{array}$ & $\frac{\text { SG and CG: }}{8-12 \mathrm{yr}}$ & English & $\begin{array}{l}\text { PTA, IQ scores } \\
\text { measured with } \\
\text { BCRS or TONI }\end{array}$ & $\begin{array}{l}\text { ABR (Click), } \\
\text { PTB, AP, LC, } \\
\text { MW, Cross- } \\
\text { Out, WA, } \\
\text { WRAT, CTOPP }\end{array}$ & $\begin{array}{l}\text { Only the processes involved } \\
\text { in encoding complex signals, } \\
\text { such as speech, are impaired in } \\
\text { children with learning problems }\end{array}$ \\
\hline
\end{tabular}

SG - Study Group; Yr - Years; PTA - Pure Tone Audiometry; WIP - Word Intelligibility Performance Task; CG - Control Group; SA - Speech Audiometry; ABR - Auditory Brain Response; APD - Auditory Processing Disorder; SLI - Specific Language Impairment; TD - Typical Development; AP - Auditory Processing; MLU - Mean Length of Utterance; TELD - Test of Early Language Development; PDS - Persistent Developmental Stuttering; SSI-3 - Persian Version of the Stuttering Severity Instrument-3; IQ - Intelligence Quotient; WASI - Weschler Abbreviated Scales of Intelligence; Moca - Montreal Cognitive Assessment; NH - Normal Hearing; SSQ - Speech, Spatial and Qualities of Hearing Scale; SIN - Self-Reported Speech-In-Noise; NL - Normal Learning; TOWRE - Test of Oral Word Reading Efficiency; OLD - Other Learning Disabilities; SDT - Speech Discrimination Testing; TOSWRF - Test of Silent Word Reading Fluency; TOAE - Transient Otoacoustic Emissions; TONI - Test of Nonverbal Intelligence; LP - Learning Problems; BCRS - Brief Cognitive Rating Scale; PTB - Psychoeducational Test Battery; LC - Listening Comprehension; MW - Memory for Words; WA - Word Attack; WRAT-3 - Wide Range Achievement Test-3; CTOPP - Comprehensive Test of Phonological Processing.

The aging process from a speech ABR perspective has been assessed by Mamo et al. [20]. Elderly subjects were found to have a reduced neural synchronicity to complex acoustic stimuli, such as speech, especially when the speech perception occurred in noisy environments. The ability to encode speech sounds in noise is related to the ability to process temporal aspects of speech. Speech ABR studies describe changes in neural morphology and measure the time delay of neural responses [21,22]. In addition, the 2013 study by Clinard et al. [23] on elderly subjects reported changes in the coding of speech sounds in the auditory brainstem. Interestingly, evaluation of hearing thresholds using pure tone audiometry did not detect any change. The data from this study suggests that electrophysiological tools can monitor the effects of aging on the central auditory system, and perhaps even predict future decline.

The association between hearing loss and speech ABR has been facilitated by technological advances in modern hearing aids, which enable new assessment procedures to 
be undertaken. In the 2015 study by Bellier et al. [24], 4 normal hearing adults were evaluated in two modalities: (i) with speech stimuli wirelessly transmitted to the hearing aid; or (ii) by using insert earphones. The data show that the auditory stimulation with hearing aids generates a speech ABR response of high quality, free of artifacts. The data suggest that important information provided by speech $A B R$ can assist the hearing aid fitting process. It may be that a similar protocol could be applied to cochlear implants in order to facilitate the adjustment of electrode mapping and in neural response telemetry (NRT) measurements.

The largest fraction of the studies (33.3\%) were performed with native English speakers, which is explained by the fact that Dr Kraus, the leading researcher and creator of the speech stimulus, did their work at Northwestern University, USA. However, wide dissemination of findings in international journals has prompted other researchers to evaluate native speakers of eight different nationalities and languages: Arabic, Brazilian Portuguese, English-UK, French, Greek, Japanese, Persian, and Portuguese. A good correlation with the findings with standard USEnglish-speaking individuals has been reported (see Table 1 for references).

In the preliminary evaluations related to the selection of participating subjects, different clinical procedures have been followed. Pure tone audiometry has been the most common, used in $95.2 \%$ of articles, and in $23.8 \%$ of the papers was the only audiological test applied.

In terms of additional evaluating procedures, different trends are apparent. In the majority of papers (47.6\%), another clinical procedure was used to evaluate the results of speech ABR; in $38.1 \%$ of the papers speech ABR appeared to be the only audiological procedure; and in $14.3 \%$ speech ABR was accompanied by click ABR. The papers of Elkabariti et al. [17] and Song et al. [16] suggest that there is a difference in $\mathrm{ABR}$ responses when click and speech stimuli are used. The data from these studies shows that only verbal stimuli are able to generate ABR responses which can be used to identify neural changes in the brainstem of individuals with epilepsy and learning difficulties. The 2011 article of Rana et al. [3] suggests that a protocol based on transiently evoked otoacoustic emissions (TEOAEs) and speech ABR makes the screening test-battery more sensitive; it can result in a more accurate diagnosis as well as identify the location of possible hearing disorders.

In order to improve the quality and efficiency of the speech ABR procedure, other syllables, apart the stimulus /da/, are being developed, and are usually composed of consonantvowel pairs. The new protocols include bi-syllabic stimuli and various modalities for stimulation such as monaural or binaural presentations [12,21,25,26]. Ahadi et al. [25] and Anderson et al. [21] found that the response time of speech $\mathrm{ABR}$ is not associated with the stimulus presentation mode, and that binaural stimulation produces more robust neural responses. Anderson et al. report that the ABR response to binaural presentation in noise was degraded in comparison to presentations in quiet. Kouni et al. [12], working with the Greek-speaking subjects, used the two-syllable stimulus /baba/ (corresponding to the word 'daddy' in English). Akhoun et al. [26] also noted that the /ba/ syllable is a good one for high quality speech ABR recordings. Neurophysiological responses obtained with the syllable /ba/ are similar to those obtained with the syllable /da/ in terms of transients and sustained portions (consonant and vowel).

A number of papers have analyzed the reliability of speech $\mathrm{ABR}$ responses in test/retest scenarios, both in young normal adults and in normal and pathological children, and this work has demonstrated the stability and replicability of neural responses $[27,28]$. In fact, speech ABR observed in groups of normal and pathological children has identified parameters which contribute to good sensitivity and specificity [14].

The conclusions reached by surveying the literature are that speech ABR is an objective assessment tool for investigating auditory function, and can be applied to different populations and age groups, irrespective of the attention of the individual. It has good clinical applicability and effectiveness, giving reliable answers. In addition, because the stimulus employed in speech ABR appears to have universal representation, the speech encoding process in speakers of different languages can be investigated, where it seems to provide good diagnostic power [29-31].

However, to better understand the auditory system, the importance of correlating speech ABR findings with other hearing assessment methods was highlighted. Further evaluations through TEOAEs or click ABRs [3] suggest that only verbal stimuli are able to identify neural changes in the brainstem region in individuals with disorders $[16,17,19]$. In the case of elderly patients, assessments using speech ABR and tone burst audiometry are effective in monitoring the aging process, whereas audiometry alone cannot identify these changes [23]. Speech ABR can be used to test auditory processing in school age children [28], and in the differential diagnosis and early identification of children at risk of learning problems [12]. There are promising opportunities for monitoring children with a family history of reading difficulties [19], and in understanding how perception of speech in noise occurs [21,23]. There is now good agreement on the steps required for assessment and reassessment $[27,28]$, as well as how to ensure adequate sensitivity and specificity [14].

Finally, it is worth emphasizing one aspect of the recent study by Bellier et al. [24] which presented ABR speech stimuli through hearing aids. This provides a new tool in the adaptation and selection of these devices, ensuring a better quality of life for patients. Therefore, it is important to further elucidate the peculiarities and variables in speech ABR responses.

\section{Conclusions}

Analysis of the literature shows that the subjects most studied through the speech ABR have been young adults and/ or healthy adults. In terms of clinical applications, the favourable aspects of speech $A B R$ are that it is objective, fast, and can be applied from early childhood. It is equally effective in different languages, and can provide differential diagnoses of diseases with similar symptoms. 


\section{Acknowledgements}

The authors thank Letícia Reis Borges, Caroline Donadon, and Thais Antonelli Diniz Hein for their assistance during the project.

\section{References:}

1. Sanfins MD. Neuropatia auditiva/dessincronia auditiva: um estudo em alunos de três escolas especiais para deficientes auditivos da cidade de São Paulo. http://www.teses.usp.br/teses/disponiveis/5/5160/tde-19092014-101620/pt-br.php: Universidade de São Paulo, Faculdade de Medicina; 2004.

2. Blackburn CC, Sachs MB. The representation of steady-state vowel /eh/ in the discharge patterns of cat anteroventral cochlear nucleus neurons. J Neurophysiol, 1990; 63: 1303-29.

3. Rana B, Barman A. Correlation between speech-evoked auditory brainstem responses and transient evoked otoacoustic emissions. J Laryngol Otol, 2011; 125(9): 911-16.

4. Hornickel J, Skoe E, Nicol T, Zecker S, Kraus N. Subcortical differentiation of stop consonants relates to reading and speechin-noise perception. Proc Natl Acad Sci USA, 2009; 106(31): 13022-27.

5. Dhar S, Abel R, Hornickel J, Nicol T, Skoe E, Zhao W et al. Exploring the relationship between physiological measures of cochlear and brainstem function. Clin Neurophysiol, 2009; 120(5): 959-66.

6. Basu M, Krishnan A, Weber-Fox C. Brainstem correlates of temporal auditory processing in children with specific language impairment. Dev Sci, 2010; 13(1): 77-91.

7. Skoe E, Kraus N. Auditory brainstem response to complex sounds: A tutorial. Ear Hear, 2010; 31: 320-24.

8. Johnson KL, Nicol TG, Kraus N. Brain stem response to speech: A biological marker of auditory processing. Ear Hear, 2005; 26(5): 424-34.

9. Sanfins M, Borges L, Ubiali T, Colella-Santos M. Speech-evoked auditory brainstem response in the differential diagnosis of scholastic difficulties. Braz J Otorhinolaryngol, 2016 [in Press].

10. Tarasenko MA, Swerdlow NR, Makeig S, Braff DL, Light GA. The auditory brain-stem response to complex sounds: A potential biomarker for guiding treatment of psychosis. Front Psychiatry, 2014; 5: 142

11. Banai K, Abrams D, Kraus N. Sensory-based learning disability: Insights from brainstem processing of speech sounds. Int J Audiol, 2007; 46(9): 524-32.

12. Kouni SN, Giannopoulos S, Ziavra N, Koutsojannis C. Brainstem auditory evoked potentials with the use of acoustic clicks and complex verbal sounds in young adults with learning disabilities. Am J Otolaryngol, 2013; 34(6): 646-51.

13. Akhoun I, Moulin A, Jeanvoine A, Ménard M, Buret F, Vollaire $\mathrm{C}$ et al. Speech auditory brainstem response (speech $\mathrm{ABR}$ ) characteristics depending on recording conditions, and hearing status: An experimental parametric study. J Neurosci Methods, 2008; 175(2): 196-205.

14. Rocha-Muniz C, Befi-Lopes D, Schochat E. Sensitivity, specificity and efficiency of speech-evoked ABR. Hear Res, 2014; 317: 15-22.

15. Rocha-Muniz CN, Befi-Lopes DM, Schochat E. Investigation of auditory processing disorder and language impairment using the speech-evoked auditory brainstem response. Hear Res, 2012; 294(1-2): 143-52
16. Song JH, Banai K, Russo NM, Kraus N. On the relationship between speech- and nonspeech-evoked auditory brainstem responses. Audiol Neuro-Otol, 2006; 11(4): 233-41.

17. Elkabariti RH, Khalil LH, Husein R, Talaat HS. Speech evoked auditory brainstem response findings in children with epilepsy. Int J Pediatric Otorhinolaryngol, 2014; 78(8): 1277-80.

18. Tahaei AA, Ashayeri H, Pourbakht A, Kamali M. Speech evoked auditory brainstem response in stuttering. Scientifica (Cairo), 2014; 2014: 328646.

19. Hornickel J, Lin D, Kraus N. Speech-evoked auditory brainstem responses reflect familial and cognitive influences. Dev Sci, 2013; 16(1): 101-10.

20. Mamo SK, Grose JH, Buss E. Speech-evoked ABR: effects of age and simulated neural temporal jitter. Hear Res, 2016; 333: 201-9.

21. Anderson S, Parbery-Clark A, White-Schwoch T, Kraus N. Auditory brainstem response to complex sounds predicts self-reported speech-in-noise performance. J Speech Lang Hear Res, 2013; 56(1): 31-43.

22. Fujihira H, Shiraishi K. Correlations between word intelligibility under reverberation and speech auditory brainstem responses in elderly listeners. Clin Neurophysiol, 2015; 126(1): 96-102.

23. Clinard CG, Tremblay KL. Aging degrades the neural encoding of simple and complex sounds in the human brainstem. J Am Acad Audiol, 2013; 24(7): 590-99.

24. Bellier L, Veuillet E, Vesson JF, Bouchet P, Caclin A, Thai-Van H. Speech auditory brainstem response through hearing aid stimulation. Hear Res, 2015; 325: 49-54.

25. Ahadi M, Pourbakht A, Jafari AH, Jalaie S. Effects of stimulus presentation mode and subcortical laterality in speech-evoked auditory brainstem responses. Int J Audiol, 2014; 53(4): 243-49.

26. Akhoun I, Gallego S, Moulin A, Menard M, Veuillet E, Berger-Vachon $\mathrm{C}$ et al. The temporal relationship between speech auditory brainstem responses and the acoustic pattern of the phoneme /ba/ in normal-hearing adults. Clin Neurophysiol, 2008; 119(4): 922-33.

27. Song JH, Nicol T, Kraus N. Test-retest reliability of the speechevoked auditory brainstem response. Clin Neurophysiol, 2011; 122(2): 346-55.

28. Hornickel J, Knowles E, Kraus N. Test-retest consistency of speech-evoked auditory brainstem responses in typically-developing children. Hear Res, 2012; 284(1-2): 52-58.

29. Karawani H, Banai K. Speech-evoked brainstem responses in Arabic and Hebrew speakers. Int J Audiol, 2010; 49(11): $844-49$.

30. Rocha CN, Filippini R, Moreira RR, Neves IF, Schochat E. Brainstem auditory evoked potential with speech stimulus. Pro Fono, 2010; 22(4): 479-84.

31. Sinha SK, Basavaraj V. Speech evoked auditory brainstem responses: A new tool to study brainstem encoding of speech sounds. Indian J Otolaryngol Head Neck Surg, 2010; 62(4): 395-99. 